\title{
PENGEMBANGAN WAWASAN MENGENAI JENIS DAN BAHAYA PENYALAHGUNAAN NARKOBA BAGI PARA PEMANDU WISATA LOKAL DI KAWASAN WISATA KOTA TUA JAKARTA
}

\author{
Heryanti Utami, MM. Par \\ Program Studi Perjalanan Wisata, Fakultas Ilmu Sosial, Universitas Negeri Jakarta \\ Email: heryanti-utami@unj.ac.id
}

\begin{abstract}
At Jakarta, Kota Tua area still one of the main tourist attraction for heritage tourism. On the other hand, the night life at this area such as café, bar, night club etc makes this area become vulnerable for drugs transaction and circulation. The local tourist guide who worked at that area coming from around local area and other origin are guiding local tourist or international tourist. They located and involved directly with the communities, government, citizen and tourist so they really familiar with the misused of drugs. In this service to community, the writer wants to involved local tourist guide Kota Tua Jakarta who joined in Jakarta Good Guide together with government to involved in counter drugs misused at this area by giving and share the knowledge of drugs misused to Kota Tua visitor, including to give understanding of knowledge, attitude and skill as a professional tourist guide.
\end{abstract}

Key words: Kota Tua Jakarta, Jakarta Good Guide, drugs

\begin{abstract}
ABSTRAK
Di Jakarta, kawasan Kota Tua masih menjadi salah satu tujuan utama wisata sejarah. Di sisi lain, karena maraknya pariwisata dan kehidupan malam di daerah ini, seperti café, bar, diskotik dan sabagainya, menjadikan daerah ini rawan perdagangan dan peredaran narkoba Para pemandu wisata lokal yang berkerja di daerah tersebut berasal dari daerah sekitar Kota Tua dan daerah-daerah lainnya, bekerja mendampingi wisatawan lokal dan mancanegara. Mereka berada di kawasan dan terlibat secara langsung oleh komunitas, pemerintah, warga dan wisatawan, sehingga mereka benarbenar mengetahui kondisi kawasan tersebut yang rawan dengan penyalahgunaan narkoba. Dalam pengabdian kepada masyarakat, penulis mencoba untuk melibatkan pemandu wisata lokal Kota Tua Jakarta yang tergabung di dalam Jakarta Good Guide untuk bersama-sama dengan pemerintah agar terlibat dalam penanggulangan penyalahgunaan narkoba di kawasan terbut dengan memasukkan materi tentang pengetahuan dan penyalahgunaan narkoba tersebut kepada pengunjung Kota Tua Jakarta, termasuk memberikan pengetahuan dari sisi knowledge, attitude dan skill sebagai pemandu wisata professional.
\end{abstract}

Kata Kunci: Kota Tua Jakarta, Jakarta Good Guide, Narkoba

\section{PENDAHULUAN}

Pariwisata adalah salah satu industri andalan yang harus terus ditumbuhkembangkan oleh suatu negara karena terbukti mampu menyumbang devisa secara signifikan. Pariwisata yang berkembang dengan baik akan mendatangkan para wisatawan nusantara (wisnus) dan wisatawan mancanegara (wisman). Dengan banyaknya wisatawan yang datang maka secara tidak langsung akan juga meningkatkan penghasilan masyarakat daerah tersebut.
Salah satu hal yang paling terlihat dampaknya adalah penggunaan narkoba. Penggunaan narkoba ini tidak hanya oleh para wisatawan saja, namun banyak sekali warga sekitar daerah tujuan wisata yang turut mengkonsumsi narkoba. Daerah rawan narkoba dan juga objek wisata favorit yang rawan peredaran narkoba salah satunya dalah Kawasan Kota Tua Jakarta. Terbukti dengan banyaknya masyarakat yang terjaring razia narkoba yang dilakukan oleh pemerintah dalam hal ini BNN (Badan Narkotika Nasional) di kawasan objek wisata tersebut. 
Dikutip dari Liputan 6 SCTV, Minggu (1/12/2013), pesta malam minggu yang digelar muda-mudi di kawasan wisata Kota Tua, Jakarta Barat, tiba-tiba dikejutkan dengan kehadiran puluhan petugas Badan Narkotika Nasional Provinsi (BNNP) Jakarta. Mereka melakukan tes urin kepada puluhan pengunjung untuk mengetahui apakah mereka mengonsumsi narkoba atau tidak. Setelah dilakukan tes urine terhadap 71 pengunjung, petugas mendapati 14 di antaranya positif mengosumsi narkoba. Operasi ini merupakan salah satu cara BNNP untuk menekan peredaran narkoba di kalangan remaja. Selain di kawasan Kota Tua, tempat hiburan malam di sekitanyapun turut di razia.

Maraknya narkoba di Kota Tua Jakarta pada akhirnya Presiden Joko Widodo menghadiri acara peringatan Hari Anti Narkotika Internasional (HANI) di Lapangan Parkir, Jalan Cengkeh, Taman Sari, Kota Tua, Jakarta Barat. Acara tersebut diselenggarakan pada hari Minggu tanggal 26 Juni 2016 lalu. Acara peringatan HANI tersebut diselenggarakan oleh Badan Narkotika Nasional (BNN).

Kota tua adalah sebuah kawasan kota yang sebelumnya dibangun oleh pemerintahan Belanda sebagai pusat perdagangan di Asia. Karena letaknya berada di tengah kepulauan Indonesia, akhirnya menjadikan Batavia (Jakarta) sebagai pusat perdagangan dari dan keluar negeri menggunakan pelayaran.

Jakarta, merupakan ibukota Negara Indonesia yang perkembangan pariwisatanya sangat pesat. Salah satu andalan pariwisata adalah Kota Tua Jakarta.

Kota Tua merupakan kota peninggalan jaman kolonial Belanda sebagai pusat pemerintahan Kota Batavia (sebutan Jakarta pada saat itu). Wisata Kota Tua Jakarta adalah wisata yang sangat popular di masyarakat Indonesia, dikarenakan banyak masyarakat yang datang ke Kota Tua Jakarta untuk melihat dan mengenang sejarah yang ada di Kota Tua tersebut.

Kota Tua merupakan tempat wisata yang mengandung banyak sejarah dan mengandung banyak pengetahuan. Di Jakarta memang banyak sekali tempat wisata yang terkenal, selain Monumen Nasional Jakarta, kota tua ini merupakan tempat wisata yang juga sering dikunjungi oleh wisatawan lokal maupun luar negeri. Selain suasananya yang sangat indah, Kota Tua Jakarta memang selalu ramai dikunjungi oleh para remaja untuk berwisata kuliner atau berfoto-foto. Dengan demikian, Kota Tua seringkali menjadi tempat untuk berkumpulnya anak-anak muda Jakarta. Sayangnya, dengan semakin populernya Kota Tua Jakarta sebagai objek wisata, semakin tinggi pula tingkat pemakaian narkoba di kawasan tersebut. Hal ini terbukti dengan berkali-kalinya pihak pemerintah, dalam hal ini BNN (Badan Narkotika Nasional) mengadakan razia di kawasan tersebut dan berhasil menangkap tangan pengguna narkoba.

Pihak pemerintah beberapakali juga mengadakan diskusi dan penyuluhan tentang bahaya narkoba di kawasan Kota Tua Jakarta, namun sayangnya masih banyak masyarakat dan pendatang yang masih saja terus menggunakan narkoba di sekitar kawasan. Pada peringatan HANI (Hari Anti Narkotika Internasional) diselenggarakan oleh Badan Narkotika Nasional (BNN), Presiden Joko Widodo bahkan hadir di Lapangan Parkir, Jalan Cengkeh, Taman Sari, Kota Tua, Jakarta Barat. Dalam acara ini, Presiden berpidato mengenai bahaya dan pemberantasan narkotika di Indonesia. Selain itu, juga akan diberikan penghargaan kepada para pegiat antinarkoba. Dalam acara itu, BNN juga akan memperkenalkan K-9, pasukan khusus pendukung pemberantasan narkoba.

Penyalahgunaan narkoba di Kawasan Kota Tua Jakarta ini seringkali dikaitkan dengan kegiatan pariwisata yang ada di sekitar kawasan. Kota Tua Jakarta memiliki sejumlah objek wisata sejarah, kuliner dan hiburan malam. Penyebaran atau distribusi narkoba seringkali ditemui berasal dari pusat-pusat hiburan malam.

Menurut buku advokasi pencegahan penyalahgunaan narkoba bagi petugas lapas dan rutan pemahaman tentang bahaya penyalahgunaan narkoba,

Jurnal Sarwahita Vol. 14 No. 02 Tahun 2017| 100 
"Narkoba merupakan singkatan dari Narkotika, Psikotropika dan Bahan Adiktif lainnya. Terminologi narkoba familiar digunakan oleh aparat penegak hukum; seperti polisi (termasuk didalamnya Badan Narkotika Nasional), jaksa, hakim dan petugas Pemasyarakatan. Selain narkoba, sebutan lain yang menunjuk pada ketiga zat tersebut adalah Napza yaitu Narkotika, Psikotropika dan Zat Adiktif. Istilah napza biasanya lebih banyak dipakai oleh para praktisi kesehatan dan rehabilitasi. Akan tetapi pada intinya pemaknaan dari kedua istilah tersebut tetap merujuk pada tiga jenis zat yang sama."

Seperti yang dikutip dari Buku panduan BNN, Pelajar dan Bahaya Narkotika, Deputi Bidang Pencegahan Direktorat Diserminasi Informasi, Jakarta 2010, Narkoba atau NAPZA merupakan bahan/zat terlarang yang apabila masuk ke dalam tubuh akan mempengaruhi tubuh terutama susunan syaraf pusat/otak sehingga bilamana disalahgunakan akan menyebabkan gangguan fisik, psikis/jiwa dan fungsi sosial. Dikatakan pula Narkotika dan Obat-obatan terlarang (NARKOBA) atau Narkotik, Psikotropika, dan Zat Aditif (NAPZA) adalah bahan / zat yang dapat mempengaruhi kondisi kejiwaan / psikologi seseorang (pikiran, perasaan dan perilaku) serta dapat menimbulkan ketergantungan fisik dan psikologi.

Narkotika adalah zat atau obat yang berasal dari tanaman atau bukan tanaman baik sintetis maupun semisintetis yang akan menyebabkan perubahan kesadaran, mengurangi sampai menghilangkan rasa sakit dan dapat menimbulkan ketergantungan (adiksi). Jenis Narkotika yang sering disalahgunakan adalah morfin, heroin (putauw), petidin, termasuk ganja atau kanabis, mariyuana, hashis dan kokain. Adapun yang dimaksud dengan golongan Psikotropika adalah zat atau obat baik alami maupun sintetis namun bukan Narkotika yang berkhasiat aktif terhadap kejiwaan (psikoaktif) melalui pengaruhnya pada susunan syaraf pusat sehingga menimbulkan perubahaan tertentu pada aktivitas mental dan perilaku, demikian menurut Agus dalam buku pedoman praktis mengenai Penyalahgunaan Napza bagi Petugas.

Pemerintah telah memberlakukan Undang-Undang untuk penyalahgunaan narkoba yaitu UU No.5 tahun 1997 tentang Psikotropika dan UU No.22 tahun 1997 tentang Narkotika. Narkotika menurut UU RI No 22 / 1997, Narkotika, yaitu zat atau obat yang berasal dari tanaman atau bukan tanaman baik sintetis maupun semisintetis yang dapat menyebabkan penurunan atau perubahan kesadaran, hilangnya rasa, mengurangi sampai menghilangkan rasa nyeri, dan dapat menimbulkan ketergantungan.

Pemandu Wisata Lokal yang bertugas di sekitar kawasan Kota Tua adalah asset yang sangat bernilai bagi kemajuan pariwisata Kota Tua Jakarta. Mereka sangat mengerti tentang sejarah, budaya dan wisata Kota Tua Jakarta. Mereka banyak sekali berinteraksi dengan masyarakat sekitar dan wisatawan mancanegara dan nusantara, sehingga menurut penulis, para pemandu wisata local ini merupakan kunci keberhasilan program pemberantasan narkoba. Mereka dapat memberikan pelayanan wisata sekaligus menjadi duta untuk pemberantasan narkoba di kawasan Kota Tua Jakarta.

Pemandu wisata adalah seseorang yang bertugas membantu para wisatawan untuk mengetahui lokasi dan seluk - beluk lokasi wisata yang dituju (NANA SUPRIATNA). Menurut Kamus Besar Bahasa ndonesia (KBBI) Pramuwisata adalah petugas pariwisata yang berkewajiban memberi petunjuk dan informasi yg diperlukan wisatawan.

Untuk meningkatkan pengetahuan para pemandu lokal tersebut perlu diberikan pengetahuan dan wawasan mengenai jenis dan bahaya penyalahgunaan narkoba. Melalui program pengabdian masyarakat bertema PENGEMBANGAN WAWASAN MENGENAI JENIS DAN BAHAYA PENYALAHGUNAAN NARKOBA BAGI PARA PEMANDU WISATA LOKAL DI KAWASAN WISATA KOTA TUA JAKARTA, diharapkan dapat meningkatkan keahlian, pengetahuan dan wawasan para 
pemandu tersebut sehingga informasi mengenai narkoba ini dapat di sampaikan dalam pekerjaannya, yaitu memberikan informasi wisata kepada para wisatawan, selain mereka membantu upaya pemerintah dalam memberantas narkoba.

Berdasarkan latar belakang diatas maka pengabdian ini difokuskan pada bagaimana meningkatkan pengetahuan dan wawasan para pemandu lokal mengenai jenis dan bahaya penyalahgunaan narkoba sehingga mereka dapat membantu upaya pmerintah dalam memberantas narkoba di Kawasan Kota Tua Jakarta.

\section{METODE PENELITIAN}

Untuk pencapaian tujuan dan kemanfaatan atas kegiatan pengabdian tersebut maka terdapat beberapa langkah teknis yang akan dilakukan dalam kegiatan pengabdian ini yaitu:

Pemberian materi dalam bentuk penyuluhan agar mereka mampu membuat modul/buku panduan sebagai pedoman dalam pengembangan wawasan para pemandu wisata.

Peserta adalah para pemandu lokal sebanyak 10 orang pemandu resmi dibawah naungan Jakarta Good Guide. Pada saat pelaksaanaan kegiatan pengabdian ini akan melibatkan materi dan pembekalan dari BNN (Badan Narkotika Nasional) sebagai narasumber.

Pembekalan dalam bentuk ceramah bervariasi dan diskusi yang mudah dipahami oleh para pemandu lokal sebanyak 10 orang yang berada di bawah naungan Jakarta Good Guide. Pembekalan untuk menambah pengetahuan dan wawasan untuk berinteraksi dan berkomunikasi. Tanya jawab yang untuk memperkuat pemahaman para pemandu terhadap materi ceramah dan praktek pemanduan.

Diakhir sesi pelatihan ini peserta akan diminta untuk membuat rencana pemanduan dan kegiatan yang berkaitan dengan pemberantasan narkoba di daerah sekitar Kota Tua Jakarta.
Kegiatan pelatihan dilakukan pada bulan April 2017. Untuk persiapan hingga pelaporan dimulai dari April sampai dengan September 2017.

\section{HASIL DAN PEMBAHASAN}

Jakarta Good Guide merupakan sebuah wadah yang memiliki kegiatan pemanduan wisata di Jakarta, terutama di Kota Tua Jakarta. Berdiri sejak September 2014 dan diprakarsai oleh Farid dan Chanda. Pertama kali mereka mengadakan kegiatan city tour di Jakarta dan kemudian mulai melakukan kegiatan walking tour di Jakarta.

Jakarta Good Guide ini memiliki kantor di Gedung Olveh Lt.3 Jl. Jembatan Batu No. 50, Pinangsia, Tamansari, Jakarta Barat. Dalam kegiatannya, Jakarta Good Guide telah menyelenggarakan perjalanan ke berbagai tempat di Jakarta, yaitu:

City Center 1

Monas

Museum Nasional

Mahkamah Konstitusi

Istana Presiden

Mesjid Istiqlal

Katedral Jakarta

City Center 2:

Lapangan Banteng

Hotel Borobudur

Gedung Pancasila

Gereja Immanuel

Galeri Nasional

Kedutaan Vatikan

Rumah PLN

Patung Pahlawan

Kedutaan USA

Kota Tua:

Museum Bank Indonesia

Sungai Besar

Toko Merah

Jembatan

Pelabuhan Sunda Kelapa

Lapangan Fatahillah

Kota Cina:

Candra Naya

Petak Semnbilan

Dharma Bakti

Gereja Santa Maria de Fatima 
E-ISSN: 2597-8926

Toa se Bio

Gloria Food street

Menteng:

Taman Suropati

Museum Kebangkitan Nasional

Sekolah Obama

Museum Nasional

Kunstkring Art Gallery

Mesjid Cut Mutia

Pasar Baru:

Stasiun Juanda

Gedung Filateli

Gedung Seni

Lapangan Banteng

Kementerian Keuangan

Gedung Antara

Pasar Baru

Gereja PNIEL

Cikini:

Gedung Joeang 45

Taman Ismail Marzuki

SMPN 1 Jakarta

Perguruan Cikini

Pasar Antik jl. Surabaya

Jatinegara:

Stasiun Jati Negara

Pasar Rawa Bening

Gedung Ex kodim

Shia Djin Kong

Masjid Al Anwar

Pasar Barang Bekas

Gereja St. Maria de Fatima

Kampung Pulo

Wihara Amurva Bhumi

GerejaKoinonia

Adapun struktur organisasi Jakarta Good

Guide adalah sebagai berikut:

Founder / Ketua: Farid Mardhiyanto

Co-Founder / Wakil Ketua: Candha Adwitiyo

Div. Walking Tour: Farid Mardhiyanto

Div. Private Tour: Candha Adwitiyo

Div. Guide Development: Indra Diwangkara

Div. Procurement: Huans Sholehan

Div. Financial: Rosalina Rita

Div. Marketing: Lelly Faizah

Pemandu Wisata Utama:

1. Farid Mardhiyanto

2. Candha Adwitiyo

3. Indra Diwangkara

4. Huans Sholehan

5. Lelly Faizah

Secara resmi Jakarta Good Guide hanya memiliki 8 (delapan) pemandu resmi tetap, sisanya adalah tenaga pemandu free lance yang bekerja apabila mereka memerlukan tambahan pemandu wisata.

Kegiatan Pelatihan pengembangan wawasan tentang penyalahgunaan narkoba ini merupakan kegiatan pelatihan yang di berikan oleh tim Dosen D3 Usaha Jasa Pariwisata kepada para pemandu wisata local di Kawasan Kota Tua Jakarta yang berada dibawah naungan Jakarta Good Guide. Pemandu yang mengikjti kegiatan ini sebanyak 10 orang.

Pemilihan pemandu wisata lokal sebagai peserta pada pelatihan ini adalah karena mereka merupakan front liner (garda terdepan) dari penyedia jasa informasi di Kawasan Kota Tua tersebut. Mereka memiliki peran sebagai penyedia jasa informasi, penunjuk lokasi di kawasan dan juga sebagai orang yang paling sering berada di kawasan ini, sehingga mereka menjadi insan yang sangat menentukan citra sebuah kawasan wisata. Dalam hal ini adalah Kawasan Kota Tua Jakarta yang memang sedikit banyak memiliki citra negative berkenaan dengan masalah narkoba

Pelaksanaan dari kegiatan pelatihan ini di lakukan melalui tiga tahapan yaitu, tahapan perencanaan (preactivity), pelaksanaan (during activity) dan tahapan akhir dari kegiatan (after activity).

Preactivity merupakan tahapan perencanaan kegiatan yang akan dilakukan. Pada tahapan ini tim membuat melakukan analisis awal akan kondisi pelayanan yang di berikan para pemandu wisata melalui berbagai berita terkait dengan kasus penyalahgunaan narkoba yang sering terjadi di Kawasan Kota Tua Jakarta. Analisis ini juga dilakukan melalui diskusi dengan beberapa pemandu wisata dan para pengguna jasa mereka, yaitu wisatawan dan pengunjung. Hasil dari diskusi tersebut maka tim menyusun materi yang akan di sampaikan dalam kegiatan pelatihan. Adapun materi yang disusun adalah tentang 
pengertian narkoba, jenis-jenis narkoba, dampak pemakaian narkoba samapai caracara pencegahan penyalahgunaan narkoba. Setelah materi pelatihan di susun maka langkah selanjutnya adalah dengan menyusun kerangka agenda kegiatan pelatihan baik secara tehnis dan non tehnis termasuk pada penentuan tanggal dan lokasi kegiatan pelatihan.

Setelah tahap pertama selesai maka dilanjutkan dengan during activity kegiatan sesuai dengan tanggal dan lokasi yang telah ditetapkan. Pada kegiatan ini pemateri yang dalam hal ini adalah tim, tidak hanya menyampaikan materi pelatihan dan sosialisasi kepada para pemandu wisata, akan tetapi juga menyerap semua informasi yang diberikan oleh para peserta terkait kondisi lapangan yang berhubungan dengan narkoba dan penyalahgunaannya.

Informasi yang diberikan oleh para pemandu wisata berupa hasil pengalaman mereka yaitu ketika berada di kawasan dan kemungkinan berinteraksi para pemakai narkoba tersebut.

Selain itu dalam pelatihan ini tim juga menyerap segala permasalahan yang sering ditemui oleh para pemandu wisata dalam menjalankan aktivitas pekerjaannya seharihari khususnya ketika berada dikawasan yang seringkali menjadi tempat terjadinya transaksi jual-beli narkoba. Segala permasalahan yang di sampaikan oleh para pemandu wisata tersebut kemudian di kaji bersama dengan tim untuk dicari jalan pemecahannya (problem solving) dengan berlandaskan pada teori dan pengetahuan yang di miliki oleh tim. Permasalahan yang disampaikan oleh pemandu wisata ini juga dijadikan literatur bagi tim pemateri terkait kondisi aktual lapangan khususnya dalam hal penyalahgunaan narkoba.

Tahap terakhir dari kegiatan pelatihan ini adalah after activity dengan melakukan evaluasi dan penyusunan laporan kegiatan. Pada tahap ini evaluasi yang dilakukan adalah me-review kembali hasil diskusi interaktif yang terbangun selama kegiatan berlangsung. Evaluasi ini diberikan setelah kegiatan penyampaian materi oleh tim dan diskusi interaktif bersama para pemandu wisata secara berlangsung. Alat evaluasi ini adalah berupa pertanyaan terbuka yang diberikan secara langsung kepada para peserta. Tujuan dari evaluasi ini adalah untuk mengukur kembali pemahaman para pemandu wisata tentang pengetahuan yang terkait dengan narkoba dan penyalahgunaannya.

Mereka juga diminta untuk memberikan contoh materi pemanduan yang berisikan pula tentang pengetahuan narkoba atau pesanpesan yang terkait dengan pelarangan penggunaan narkoba, mengingat pengguna jasa mereka adalah para pelajar atau pengunjung dengan usia rentan terkena dampak narkoba.

Selain dari melakukan evaluasi pelatihan tersebut maka tahap terakhir adalah tim membuat laporan hasil kegiatan pelatihan. Laporan hasil kegiatan ini akan diserahkan kepada pihak Universitas Negeri Jakarta untuk dijadikan suatu bahan referensi akademik mengenai implementasi pelatihan dalam memerangi narkoba.

Hasil dari kegiatan pelatihan ini ternyata banyak sekali permasalahan lapangan yang disampaikan oleh para pemandu wisata khususnya yang terkait dengan narkoba dan penyalhgunaannya. Hal ini merupakan pengetahuan baru bagi tim yang selama ini hanya memahami narkoba dan bahaya serta dampaknya hanya melalui literature atau media saja. Permasalahan yang sering muncul ke permukaan dalam diskusi tersebut adalah terbagi dalam tiga bagian utama:

1. Knowledge (Pengetahuan)

Berdasarkan pada pelaksanaan kegiatan tersebut ternyata ditemukan bahwa sebagian besar peserta ternyata belum memahami secara menyeluruh mengenai pengertian dan jenis-jenis narkoba. Pengetahuan yang diberikan hanya sebatas sosialisasi massal dan sangat kurang interaktif dengan penyelenggara.

Kegiatan sosialisasi selama ini sangat bersifat umum, tidak dikhususkan bagi para pemandu wisata, sehingga mereka tidak pernah menyelipkan materi tentang narkoba Jurnal Sarwahita Vol. 14 No. 02 Tahun 2017| 104 
dalam materi pemanduannya. Hal ini terjadi pula karena dari pihak Jakarta Good Guide belum pernah mengadakan pelatihan tentang hal ini sebelumnya.

Atas dasar kondisi inilah akhirnya tim memberikan materi khusus tentang pengertian narkoba untuk di implementasikan oleh para pemandu wisata. Materi yang disampaikan adalah tentang:

a. apa yang dimaksud dengan narkoba, napza

b. bentuk-bentuk atau jeni-jenis narkoba

c. dampak-dampak penyalahgunaan narkoba

d. Cara-cara pencegahan penyalahgunaan narkoba

Pada pelaksanaan kegiatan tersebut ternyata pengetahuan yang dimiliki oleh para pemateri dirasakan manfaatnya oleh para pemandu wisata. Tidak hanya pengendara pemandu saja yang mendapatkan pengetahuan baru, tim juga mendapatkan sesuatu yang baru khususnya kondisi realita lapangan yang selama ini tidak pernah ditemukan sebelumnya. Dengan pelatihan ini tim juga pada akhirnya berdiskusi dengan para pemandu wisata lokal untuk mencari solusi terbaik dalam menghadapi permasalahan dilapangan yang terkait dengan penyalahgunaan narkoba.

Salah satu permasalahan yang sering ditemui oleh para pemandu wisata apabila kebetulan bersinggungan atau bertemu dengan para pemakai narkoba adalah mereka tidak dapat berbuat banyak untuk mencegah atau memberhentikan mereka karena terlalu riskan terjadinya bentrokan atau perkelahian diantara mereka. Belum lagi mereka jadi takut atau was-was untuk bekerja di daerah tersebut karena mereka akan diancam.

Adapun bentuk pelatihan ini antara lain memberikan mereka pengetahuan, role play, studi kasus yang mengacu pada:

\section{Attitude (sikap)}

Untuk Attitude seluruh pemandu wisata sudah sesuai dengan aturan-aturan dan kode etik pramuwisata. Mereka telah banyak mendapatkan latihan kepramuwisataan baik dari dinas pariwisata maupun dari sesame pemandu wisata.

Untuk penampilan fisik mereka sangat rapih dan cukup enak dilihat. Penampilan mereka sesuai dengan aturan penampilan seorang pemandu yaitu rambut dan pakaian mereka semua terlihat rapi dan bersih.

3. Skill (Keterampilan)

Untuk skill kepemanduan atau pramuwisata mereka sudah cukup menguasai. Mereka dapat dengan cepat dan tanggap dalam pemahaman materi dan langsung mengaplikasikannya dalam pekerjaan mereka sebagai pemandu. Bahkan materi tentang narkoba ini sendiri telah banyak mempengaruhi pengetahuan mereka dalam bidang kepariwisataan dan mereka langsung dapat mengaitkannya dengan materi pemanduan yang telah mereka miliki sebelumnya.

\section{PENUTUP}

Berdasarkan hasil pelaksanaan kegiatan pelatihan ini ternyata masih ditemukan beberapa kekurangan yang dimiliki oleh para pengendara ojek online khususnya dari sisi knowledge (pengetahuan) yang menyangkut permasalahan narkoba. Dengan kegiatan ini ternyata mampu membuka wawasan para pemandu wisata mengenai penyalahgunaan narkoba.

Kegiatan pelatihan ini juga tidak hanya bermanfaat bagi para pemandu wisata saja, namun bagi pada pemateri yang dalam hal ini adalah tim ternyata juga sangat bermanfaat, karena dengan kegiatan ini para pemateri mendapatkan informasi yang aktual mengenai realita lapangan yang berasal dari pengalaman para pemandu wisata tersebut.

Mengingat pentingnya kegiatan pelatihan ini bagi para pemandu wisata local Kota Tua Jakarta msupun para pemateri maka terdapat beberapa saran untuk di jadikan rekomendasi bagi pemegang kepentingan yaitu:

Jakarta Good Guide atau wadah dengan bentuk dan tujuan yang sejenis pemandu atapun hendaknya senantiasa memberikan pembekalan dan pelatihan mengenai masalah- 
masalah sosial yang terjadi di masyarakat. Misalnya bila kali ini adalah mengenai penyalahgunaan narkoba, kali lain mengenai masalah prostitusi ataupun pungutan liar dsb.

Senantiasa melakukan pelatihan secara berkelanjutan dan sistematis untuk meningkatkan pengetahuan, skill dan attitude pemandu wisata mengingat mereka adalah ujung tombak pariwisata dan juga aset yang berharga bagi Kota Jakarta.

Bagi pemerintah terkait bahwasanya tindakan hukum terhadap para pengguna narkoba ataupun pengedar narkoba. Perlu sosialisasikan mengenai bentuk-bentuk penyalahgunaan narkoba dan sosialisai mengenai hukum yang berlaku di Indonesia. Mengadakan razia ataupun pengawasan yang berkelanjutan sehingga dikemudian hari tidak terjadi lagi tindakan penyalahgunaan narkoba di Kawasan Kota Tua Jakarta pada khususnya sehingga citra Kota Tua Jakarta dapat terus terjaga dengan baik.

Bagi akademisi adalah senantiasa selalu menggali kondisi realita yang ada dan menjadikannya sebagai bahan kajian untuk mengembangkan strategi implementasi yang tepat sasaran dari konsep-konsep ilmu pengetahuan yang ada sehingga dapat dirasakan manfaatnya secara langsung bagi industri dan masyarakat luas.

\section{DAFTAR PUSTAKA}

Alifia, U. 2008. Apa Itu Narkotika dan Napza. Semarang: PT Bengawan Ilmu.

A, Yoeti, Oka. Edisi Revisi 2008. Pengantar Ilmu Pariwisata. Bandung: Penerbit Angkasa.

Buku Advokasi Pencegahan Penyalahgunaan Narkoba. 2009. BNN

Buku panduan BNN. 2010. Pelajar dan Bahaya Narkotika. Deputi Bidang Pencegahan Direktorat Diserminasi Informasi, Jakarta

Cooper, et al. 2005. Tourism Principles and Practice. Essex: Pearson Education
Conyers. 1994. Perencanaan Sosial di Dunia Ketiga, Suatu Pengantar. Yogyakarta: Gajah Mada University Press.

Millar, S. 1989. Heritage Management for Heritage Tourism. Tourism Management.

Moleong, Lexy J. 2012. Metodologi Penelitian Kualitatif. Bandung: Remaja Rosdakarya.

Partodiharjo, S. 2008. Kenali Narkoba dan Musuhi Penyalahgunaannya. Surabaya: Erlangga.

Spillane, J.J. 1993. Ekonomi Pariwisata Sejarah dan Prospeknya. Yogyakarta: Kanisiun.

Slamet. 1994. Pembangunan Masyarakat Berwawasan Partisipasi. Surakarta: UNS Press.

Sugiyono. 2012. Memahami Penelilitian Kualitatif. Bandung: AlfaBeta

Sastropoetro. 1988. Partisipasi, Komunikasi, Persuasi dan Disiplin Dalam Pembangunan Nasional, Bandung: Alumni.

Seabroke, W and Miles, C.W.N. 1993. Recreation Land Management. London: E \& FN SPON

Tilden, F (1078). Interpreting Our Heritage. North Carolina: The University of North Carolina Press.

Undang-Undang Kepariwisataan No. 10 Tahun 2009

Utami, Heryanti. Thesis: Optimalisasi Pengembangan Kawasan Kota Tua Jakarta sebagai Urban Heritage Tourism berbasis Experiential Marketing. Sekolah Tinggi Pariwisata Bandung. Bandung: 2010

Vanhove N. 2005. The Economics of Tourism Destinations. Elsevier. Burlington. 
DOI: https://doi.org/10.21009/sarwahita.142.03

P-ISSN: 0216-7484

E-ISSN: 2597-8926

Veverca, JA (1998). Interpretive Master Planning: The Essential Planning Guide for Interpretive. Tustin: Acorn Naturalist 